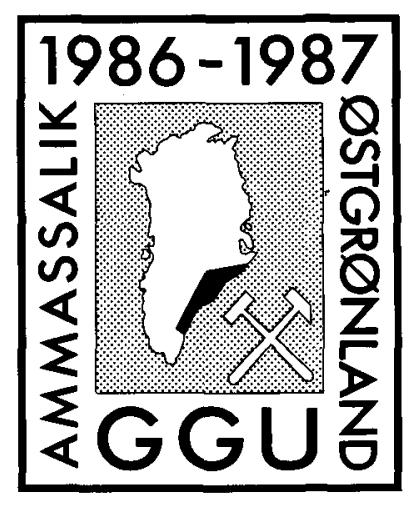

\title{
Basic dykes of the southern Ammassalik region, South-East Greenland: preliminary mineralogical and geochemical results
}

\author{
R. P. Hall, D. J. Hughes and L. Joyner
}

\begin{abstract}
The Ammassalik mobile belt of South-East Greenland and the Archaean gneisses to the north and south are cut by abundant variably deformed and metamorphosed Proterozoic basic dykes. Undeformed and unaltered dolerite dykes in the southernmost part of the region retain fresh igneous subophitic textures and mineral assemblages, the pyroxenes of which preserve complex chemical variations with highly variable $\mathrm{Ca}, \mathrm{Mg}$ and $\mathrm{Fe}$ contents. The ophitic pyroxenes in neighbouring dykes of supposed Tertiary age comprise more usual, compositionally uniform pigeoniteaugite pairs. The contrast between these pyroxene assemblages probably results largely from differences in the oxygen fugacity of their respective parental magmas. The investigated Proterozoic dykes have chemical and mineralogical similarities with dykes of the same general age in southern West Greenland and Scotland, and they pre-date the development of the Ammassalik mobile belt, rather than being directly related to it.
\end{abstract}

One of the most fundamental criteria in deciphering the evolution of the Proterozoic mobile belt in the Ammassalik region of South-East Greenland has been the interpretation of the relative age and the structural state of the abundant basic dykes which occur both marginal to and within the belt. Early reconnaissance work suggested that the basic dykes were essentially penecontemporaneous with the formation of the mobile belt and that the commonly lobate forms of the dykes within the belt are evidence of their syntectonic emplacement (Bridgwater \& Myers, 1979; Myers, 1984, 1987). These structures were seen as being analogous to the intrusive forms of some of the syn-Nagssugtoqidian Kangâmiut dykes in West Greenland (Escher et al., 1976b; Nash, 1979). Partly because of these interpretations, the Proterozoic mobile belt of South-East Greenland has always been regarded as a simple eastern extension of the Nagssugtoqidian mobile belt. However, if the basic dykes at the east coast are not part of the Kangâmiut swarm, and are not related to the formation of the mobile belt, then this also weakens the correlation of the mobile belts themselves.

Doubt has been cast on some of the early interpretations of the geology of the Ammassalik region by the subsequent reconnaissance mapping work in 1986 (Kalsbeek \& Nielsen, 1987; Chadwick et al. and Escher et al., this volume; Dawes et al., this volume - Northern boundary). In particular, it has been suggested that the present irregular forms of the basic dykes do not reflect their syn-tectonic injection, but are simply an indication of the inhomogeneous deformation of originally planar, sub-vertical dykes (Escher et al., this volume). This in turn implies that the dykes are older than the deformation associated with the formation of the mobile belt.

In the southern part of the Ammassalik region, there are three distinct types of basic dykes. The youngest swarm trends NNE and comprises widely spaced, redbrown weathering dykes up to around $60 \mathrm{~m}$ wide and continuous for several tens of kilometres. These dykes are totally unaffected by any of the mobile belt deformation but they commonly have their own $30 \mathrm{~m}$ wide epidote-rich marginal retrogression zones. These dykes are believed to be of Tertiary age. The earlier two dyke swarms are both progressively deformed and metamorphosed towards the centre of the mobile belt; they both trend roughly east-west and will in the following be referred to as the EW dykes. They are distinct from one another in that one type consists of black-weathering dolerites which become metamorphosed to hornblenderich garnet amphibolites, while the other type is noritic (orthopyroxene-rich) and weathers dark brown. These dykes become altered to orthoamphibole-rich amphibolite. Rare cross-cutting relationships demonstrate that the noritic dykes are older than the dolerites. A large suite of basic dyke samples from throughout the region was collected by RPH during the 1986 reconnaissance 

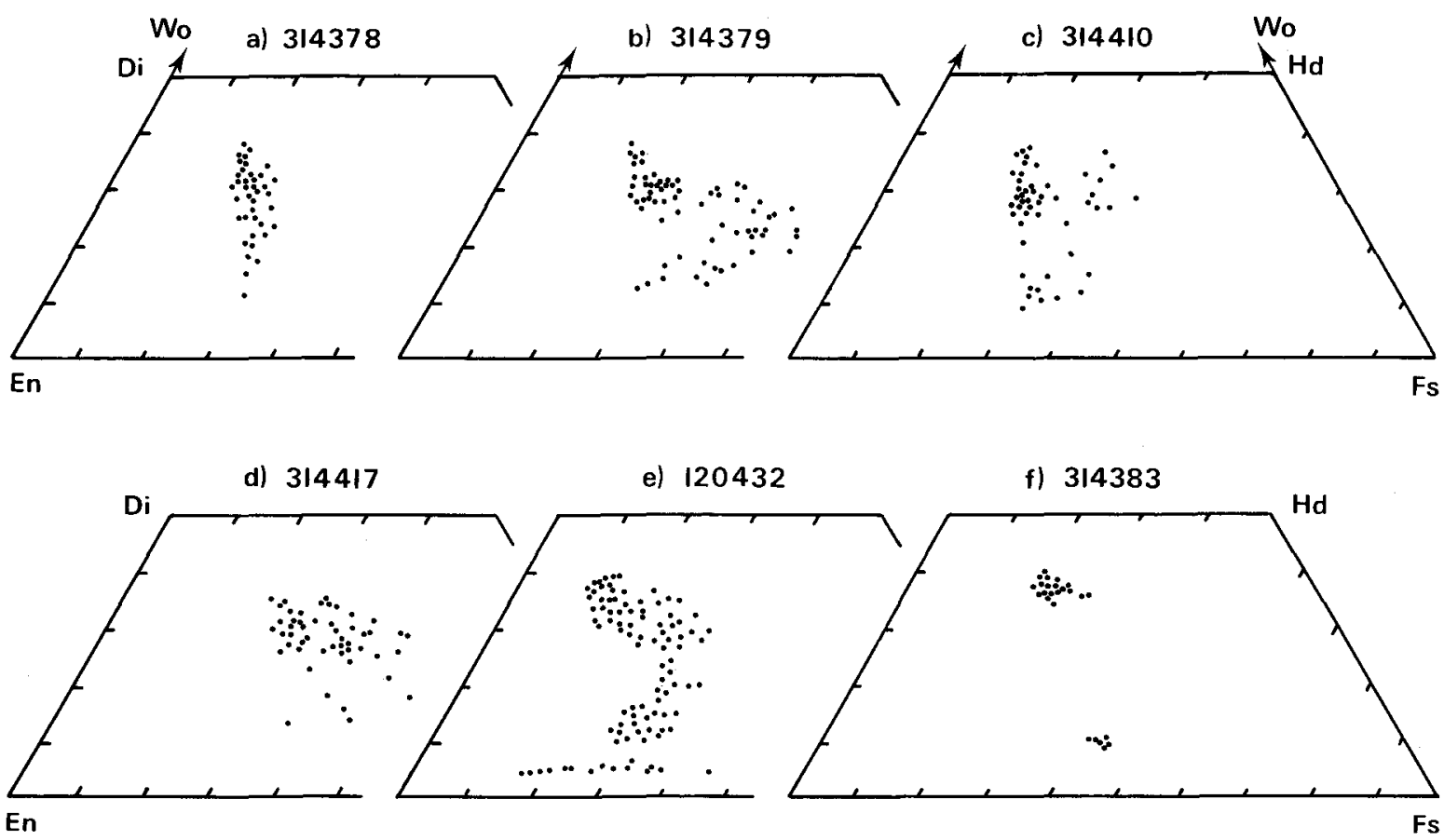

Fig. 1. Pyroxene assemblages in four EW (Proterozoic) basic dyke samples from the southern Ammassalik region (a-d), compared to that of a Tertiary dolerite dyke from the same region (f) and an MD dolerite from southern West Greenland (e; after Hall et al., 1986).

mapping work for a mineralogical and geochemical study.

There are four different swarms of early Proterozoic basic dykes in southern West Greenland to which the EW dykes could be related. These are (1) three generations of $c$. $2100 \mathrm{Ma}$ doleritic (predominantly plagioclase + clinopyroxene) dykes known as the MD dykes (Kalsbeek \& Taylor, 1985; Hall et al., 1985), (2) a younger suite of plagioclase-phyric (PP) dykes (Hall $\boldsymbol{e t}$ al., 1987c), (3) a swarm of $2100 \mathrm{Ma}$ noritic (predominantly orthopyroxene + plagioclase) dykes referred to as the BN dykes (Hall \& Hughes, 1987), and (4) the 1950 Ma Kangâmiut dykes prevalent in the southern part of the Nagssugtoqidian mobile belt (Escher et al., 1976b; Kalsbeek et al., 1978; Zeck \& Kalsbeek, 1981). The mineralogy of the basic dykes of South-East Greenland is not, by itself, diagnostic of the dykes belonging to one or another generation. However, similarity between both the pyroxene assemblages of relatively unaltered basic dykes in the southern Ammassalik region with the complex pyroxenes recognised in the MD dykes of southern West Greenland (Hall et al., 1985, 1986) and also between certain of their geochemical characteristics would lend considerable weight to the argument that they are of similar derivation. A full geochemical and mineralogical investigation of the
South-East Greenland dykes is under way. The preliminary results of this study suggest that there are distinct similarities between the EW dolerites and MD dolerites, and between the EW norite dykes and the BN norites.

The mineralogy of four relatively unaltered Proterozoic dolerite samples and one sample from a Tertiary dyke from the southern Ammassalik region has so far been examined, using the energy dispersive electron microprobe at the Department of Earth Sciences, University of Cambridge. One of the EW dyke samples (314410) is from one of the abundant dykes at the west end of Zebrafjeld (illustrated previously by Andrews $e t$ al., 1973; Bridgwater, 1976; and Myers, 1987). Two others (314378 and 314379) are from the margin and core respectively of an EW dyke outcropping on Neptunus Halvø at the southwest corner of Gyldenløve Fjord, and the fourth (314417) is from a dyke which occurs 75 $\mathrm{km}$ to the north, on the half-nunatak west of the northern tip of Jens Munk $\emptyset$. The Tertiary dyke sample is from Sadelfjeldet (see Escher et al., this volume, fig. 1).

All of the Proterozoic dyke samples have complex pyroxene assemblages, the principal variations in which -are in their $\mathrm{Ca}, \mathrm{Mg}$ and $\mathrm{Fe}$ contents. Si decreases slightly with decreasing Mg content, while the generally low $\mathrm{Ti}$ and $\mathrm{Al}$ contents correspondingly increase. The 


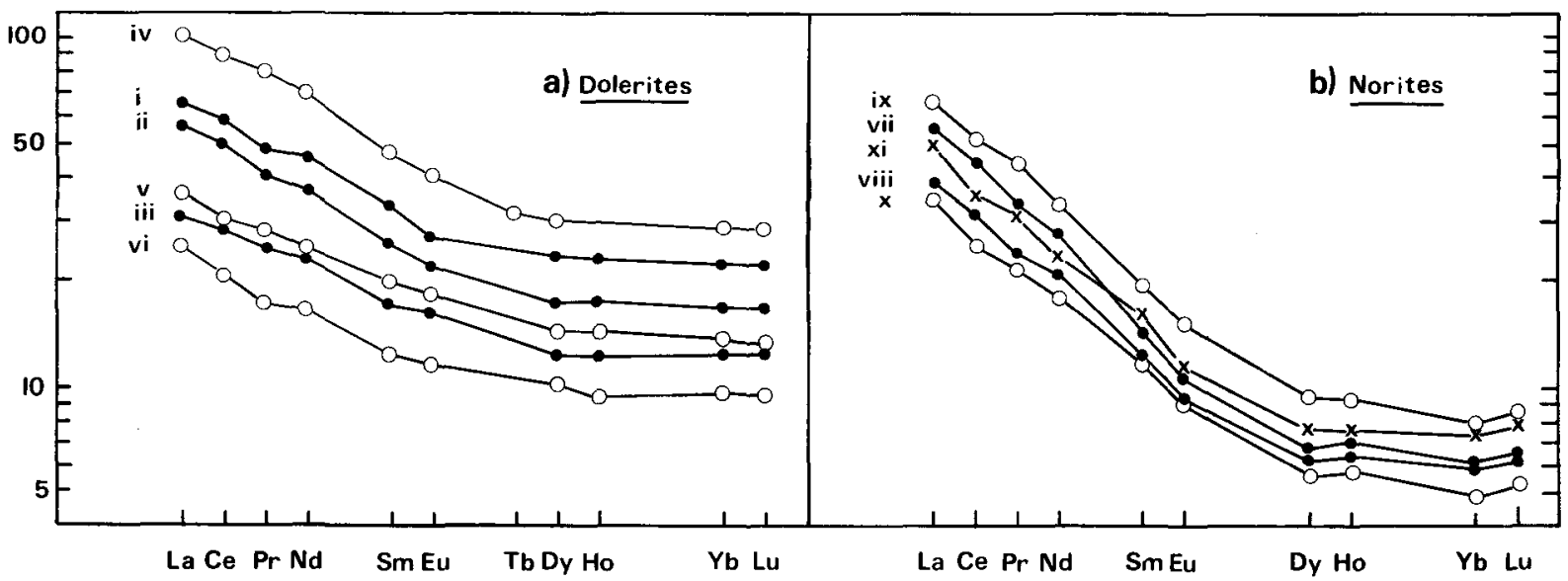

Fig. 2. Chondrite-normalised REE abundances of (a) three EW dolerite dykes of South-East Greenland (dots) compared to those in three MD dolerites of southern West Greenland (open circles), and (b) two EW norite dykes (dots) compared to two BN norites (open circles) and a Scourie norite dyke from Badcall Bay, North-West Scotland (xi: crosses).

GGU sample numbers are in (a): i: 314417; ii: 314378; iii: 314410; iv: 155686; v: 179032; vi: 149224; and in (b): vii: 314352; viii: 314430; ix: 290506; x: 220557.

REE analyses for iv and vi by neutron activation analysis at the Universities of Manchester and Liverpool Research Reactor, Warrington, U.K.; all other analyses by inductively coupled plasma-source spectrometry by Dr. N. Walsh, Royal Holloway \& Bedford New College (University of London), Egham, U.K.

major variations are shown in figure $1(a-d)$, in terms of the respective mol. Wo : En : Fs proportions, equivalent to ionic $\mathrm{Ca}: \mathrm{Mg}: \mathrm{Fe}$ proportions. Each pyroxene assemblage spans an unusually large area of the saturatedpyroxene quadrilateral. This feature is characteristic of the pyroxenes in the MD dykes of southern West Greenland (Hall et al., 1985, 1986). The assemblages include augites, ferroaugites, sub-calcic augites and pigeonites, which demonstrate not only Fe-enrichment, with $\mathrm{X}_{\mathrm{Mg}}$ values ranging from around 0.73 to 0.33 (where $X_{\mathrm{Mg}}=\mathrm{Mg} /(\mathrm{Mg}+\mathrm{Fe})$ ), but also a wide range of Ca contents. The marginal dyke sample (314378) consists of small phenocrysts of plagioclase and pyroxenes in a microcrystalline matrix. The compositions of the pyroxenes in this sample (fig. 1a) fall along a line equivalent to a coexisting augite - pigeonite pair tie-line (cf. Huebner \& Turnock, 1980), suggesting that the pyroxenes intermediate to the most calcic and Ca-poor compositions are simply co-precipitated, quenched metastable types. The sample from the core of the dyke (314379) is coarse-grained and the pyroxenes form large, sub-ophitic, compositionally complex grains. The spread of these pyroxene compositions (fig. 1b) weakly defines a pyroxene miscibility gap and an isothermal low pressure pyroxene phase boundary. Despite the lack of olivine and orthopyroxene in this sample, the comparison of the range of pyroxene compositions with the clinopyroxene assemblage in one of the most intensively studied MD dolerites from the Fiskenæsset region of southern West Greenland (Hall et al., 1986) is most striking (fig. 1e).

In contrast to the variable pyroxene assemblages in the EW dykes, the pyroxenes in the sample of Tertiary dolerite (314383) constitute a relatively simple coexisting pair of comparatively uniform augite $\left(\mathrm{Wo}_{37} \mathrm{En}_{41} \mathrm{Fs}_{22}\right)$ and pigeonite ( $\mathrm{Wo}_{10} \mathrm{En}_{47} \mathrm{Fs}_{43}$ ) (fig. 1f) more typically associated with doleritic rocks. The pyroxenes in this medium-grained sample are also sub-ophitic, and also enclose early olivine crystals $\left(\mathrm{Fo}_{60-50}\right)$. The contrast between the pyroxene assemblages in the Proterozoic and Tertiary samples clearly reflect significant differences in the compositions of the magmas from which they were derived. One major factor influencing the precipitation of highly variable pyroxene assemblages as opposed to chemically uniform ones is a low oxygen fugacity $\left(f_{\mathrm{O}_{2}}\right)$. Magmas with a relatively high $f_{\mathrm{O}_{2}}$ tend to crystallise magnetite at an early stage because of the comparatively low solubility of ferric iron, and thus the coprecipitating pyroxenes in such rocks tend to be chemically uniform and relatively magnesian (Osborn, 1959; Fodor, 1971).

The initial results suggest that the oxide phases in the EW dykes were originally ulvöspinel. They are presently oxidised to ilmenite-titanomagnetite exsolution pairs. Textural relationships in the coarser EW dyke samples demonstrate that the $\mathrm{Fe}-\mathrm{Ti}$ oxide phase precipitated relatively late in the crytallisation sequence, and it occurs as a groundmass phase rather than as phenocrysts 
in the EW dyke margin sample. The Tertiary dyke sample on the other hand contains both early and late titanomagnetite crystals which have Fe:Ti ratios of around 4.5:1 and this phase occurs as phenocrysts together with olivine, pyroxene and plagioclase phenocrysts in chilled dyke margin samples. Just as these different mineral assemblages signify a contrast between the EW and Tertiary dykes, the similarities between the EW dykes and the MD dykes of southern West Greenland are indicative of petrogenetic similarities between the parental magmas of these two swarms.

The juxtaposition of doleritic and noritic dykes in the southern Ammassalik region is closely parallelled by the coincidence of the MD dolerites and the BN norites in southern West Greenland. The BN norites have a very distinctive geochemistry which in many respects resembles that of modern boninites (Hall \& Hughes, 1987). One of their distinguishing geochemical characteristics is that although they are relatively magnesian rocks, they demonstrate light rare-earth element (LREE) enrichment and have strongly fractionated REE distributions. In contrast, the MD dolerites typically have relatively flat, unfractionated chondrite-normalised REE distribution patterns (Hall \& Hughes, 1987). This contrast is also seen, although not so markedly, in the dykes of the southern Ammassalik region (fig. 2). The noritic EW dykes from this region also have strongly fraction- ated REE distribution patterns, with light and heavy REE concentrations approximately 50 and 6 times average CI chondritic values (Evensen et al., 1978) respectively, comparing closely with the REE contents of the BN dykes. Very similar norites also form part of the early Proterozoic Scourie dyke swarm of North-West Scotland (Weaver \& Tarney, 1981; Hall \& Hughes, 1987). It is therefore possible that these distinctive noritic dykes constitute a single, very extensive swarm.

These preliminary geochemical and mineralogical findings suggest that some, at least, of the basic dykes of the southern Ammassalik region are similar to the early Proterozoic MD and BN dykes of southern West Greenland, which significantly pre-date the development of the Nagssugtoqidian mobile belt. By analogy, this lends support to the field and structural data that the EW dykes are older than the development of the Proterozoic mobile belt of South-East Greenland, and are deformed by it but not related to it, as has been suggested previously.

Acknowledgements. We are grateful to Dr. J. V. P. Long for the continued use of the electron microprobe facilities at the Department of Earth Sciences, University of Cambridge, and to Mrs. Lesley Holland (Portsmouth Polytechnic) for preparing polished sections. 